\title{
Evaluation of arrowroot agronomic performance (Maranta arundinacea) 'Seta' intercropped with sunn hemp
}

\author{
Avaliação do desempenho agronômico da araruta (Maranta arundinacea) 'Seta' consorciada com \\ crotalária
}

\section{João Nacir Colomboํ, Janiele Cássia Barbosa Vieira ${ }^{2}$, Marcelo Rodrigo Krause ${ }^{3 \star}$, Mário Puiatti ${ }^{3}$ \& Ismail Ramalho Haddade ${ }^{1}$}

${ }^{1}$ Federal Institute of Espírito Santo, Santa Teresa, ES, Brazil.

${ }^{2}$ Federal University of Pernambuco, Recife, PE, Brazil.

${ }^{3}$ Federal University of Viçosa, Viçosa, MG, Brazil. *Autor para correspondência: agro.krause@gmail.com.

Submission:25/09/2017 | Acceptance: 31/05/2018

\begin{abstract}
Because it is an unconventional vegetable, arrowroot is appropriate for family farming; there is a need to find alternative ways to make its growing more sustainable, however. The objective of this study was to evaluate the productive performance of rhizomes and starch of arrowroot 'Seta' intercropped with crotalaria. The experiment consisted of four treatments, corresponding to three harvest for crotalaria intercropped with arrowroot (90, 120 and 150 days after sowing) plus single cultivation of arrowroot. The experiment used a complete randomized block design with four replications. Mass production of crotalaria, macro and micronutrients contents in the cut material and infestation by invasive plants were evaluated at each harvest. At the harvest of arrowroot, productivity and format of rhizomes classes, macro and micronutrient contents were evaluated, and the export of nutrients and production of starch by rhizomes were estimated. The hasvests carried out at 120 and 150 DAS, despite propagating the highest values of weight and nutrients, provided lower yields of total, large rhizomes, and starch. Crotalaria hasvested at 90 DAS provided values higher than the cuts performed on 120 and 150 DAS for most evaluated variables, not differing from control, including starch. The intercropping provided less infestation by invasive plants. The intercropping between crotalaria and arrowroot provided is suitable as long as the harvest of this legume occurs up to 90 DAS.
\end{abstract}

KEYWORDS: Crotalaria juncea, green manure, starch, invasive plants.

\section{RESUMO}

A araruta, por ser uma hortaliça não convencional é apropriada a exploração familiar, havendo necessidade de se encontrar formas alternativas para tornar seu o cultivo mais sustentável. Objetivou-se avaliar o desempenho produtivo de rizomas e de amido da araruta 'Seta' cultivada em consórcio com a crotalária. O experimento constou de quatro tratamentos, correspondentes a três épocas de corte da crotalária associada com a araruta (90,120 e 150 dias após a semeadura) mais o monocultivo da araruta. Utilizou-se o delineamento experimental de blocos casualizados, com quatro repetições. Nos cortes, avaliaram-se produção de massa de crotalária, conteúdo de macro e de micronutrientes no material cortado e a infestação por plantas invasoras. Na colheita da araruta, avaliaram-se produtividade e formato das classes de rizomas, teor de macro e micronutrientes, estimadas a exportação de nutrientes e a produção de amido pelos rizomas. Os cortes realizados aos 120 e 150 DAS, embora tenham veiculado maiores valores de massa e de nutrientes, proporcionou menores produtividades de rizomas grandes, total e de amido. O corte da crotalária aos 90 DAS proporcionou valores superiores aos cortes realizados aos 120 e 150 DAS para maioria das variáveis avaliadas, não diferindo do controle, inclusive para o amido. O consórcio proporcionou menor infestação por plantas invasoras. É agronomicamente viável a associação da crotalária com a cultura da araruta desde que o corte da leguminosa ocorra até 90 DAS.

PALAVRAS-CHAVE: Crotalaria juncea, adubação verde, amido, plantas invasoras.

\section{INTRODUCTION}

The arrowroot (Maranta arundinaceae L.) belongs to the Marantaceae family. Its original source is 
likely to be the South American continent since it was found as a native plant in Venezuelan forests (HEREDIA ZÁRATE \& VIEIRA 2005). They are small size plants with conical-elongated or spindle-shaped, light rhizomes covered with scales. The most important cultivars in Brazil are "Comum", "Creoula" and "Banana", the first being the most widespread and producing better quality starch (LEONEL \& CEREDA 2002).

Rhizomes contain, according to the age of the plant, more than $20 \%$ of starch (FERRARI et al. 2005). Arrowroot plants present starch as a differential since it has unique features and qualities, providing lightness and high digestibility for baking products (cakes and cookies), as well as lack of gluten (CEREDA 2002).

The arrowroot has been framed as one of unconventional vegetables that need to be protected, according to the Ministry of Agriculture, Livestock and Supply (MAPA 2010). Unconventional vegetables are those with limited distribution, restricted to certain locations or regions, exerting great influence on the food and culture of traditional populations. Moreover, they are species that did not receive due attention from the scientific, technical community and society as a whole, and they are not organized as a productive chain (MAPA 2010).

Widely grown by farmers in the past, arrowroot has lost space in the last 50 years, having almost gotten extinct. This was due to competition from other starch species associated with supply shortages and difficulties in obtaining flour. These factors have caused the food industry to replace arrowroot starch for other species produced on an industrial level, such as cassava, corn, wheat and oats; thus, arrowroot almost disappeared from the market (CEREDA 2002).

Currently, the food industries have shown, again, great interest in the arrowroot starch due to its characteristics. The high demand and small supply have raised the price on the international market, becoming higher than similar products. This has also aroused interest in the arrowroot growing in Brazil, mainly by family farmers (CEREDA 2002).

Family farming is characterized by the diversified agricultural production, a limitation of physical space and financial resources. These characteristics, together with the intensive cultivation, may lead to soil depletion. An alternative way to contribute to conservation and nutrient supply for the soil is to use green manure plants, in particular, legumes. However, crop rotation with green manure legumes in family farming estates has the limited physical area as a restriction. For such situations, intercropping valuable crops with green manure legumes becomes an interesting option (PUIATTI et al. 2015).

In intercropping, Crotalaria juncea has been the most commonly used legume as green manure because it is a fast-growing, vigorous, annual plant, with erect stem, good biomass production, which is able to fix atmospheric N2 and recycle various soil profile nutrients (VARGAS et al. 2011). It is a legume that has the highest rate of decomposition, in which, during the first 60 days, 40 to $60 \%$ of residual biomass is decomposed with $32 \%$ of the total $\mathrm{N}$ present in the plant material released in the first 15 days (MOURA et al. 2005).

However, in intercrops, aside from the species, the amount of mass and nutrients contributed by the green manure depends on planting and harvesting or pruning seasons as well as management provided to plant mass (SOUZA \& GUIMARÃES 2013, PUIATTI et al. 2015). Thus, the careful choice of the intercropping component crops, the time of their respective establishments and management of harvest or pruned mass are of fundamental importance (PUIATTI et al. 2015). In this respect, the management of plant mass associated with leguminous plants is important because the residual $\mathrm{N}$ from crop residues should be considered and maybe used by subsequent cultures (SOUZA et al. 2015).

Therefore, intercropping vegetables with green manure legumes may be an interesting alternative, especially for small estates of family farming, since it reduces the use of mineral fertilizer, which makes production less dependent on the external market.

Experiments involving the use of green manure intercropped with vegetables such as peppers (CESAR et al. 2007), cabbage and radish (OLIVEIRA et al. 2005), and taro (PUIATTI et al. 2015) have shown positive results; however, their response varies according to pruning time of crotalaria. However, there are few studies on arrowroot.

Thus, the objective of this study was to evaluate the productive performance and the starch content of arrowroot "Seta" intercropped with Crotalaria juncea in three legume harvests.

\section{MATERIAL AND METHODS}

The experiment was carried out on the field, at the horticultural sector of the Federal University of Viçosa (UFV), Viçosa, Minas Gerais State, from October, 2012 to September, 2013. The municipality of Viçosa is $650 \mathrm{~m}$ above sea level, at $20^{\circ} 45^{\prime} 47^{\prime \prime} \mathrm{S}$ latitude and $42^{\circ} 49^{\prime} 13^{\prime \prime} \mathrm{W}$ longitude. According to the Köppen 
classification, it has a climate of type "Cwa" (humid subtropical climate), with average annual rainfall of 1,341 $\mathrm{mm}$ and maximum and minimum temperatures of $21.6^{\circ} \mathrm{C}$ and $14^{\circ} \mathrm{C}$, respectively.

The soil in the experimental area is classified as loamy Red-Yellow Argissol, clay texture, whose sampling at the depth of $0-20 \mathrm{~cm}$ presented the following results:: $\mathrm{pH}_{\text {(water) }}=6.4 ; \mathrm{P}=180$ and $\mathrm{K}=102 \mathrm{mg}$ $\mathrm{dm}^{-3} ; \mathrm{Ca}^{2+}=5.0 ; \mathrm{Mg}^{2+}=0.7 ; \mathrm{Al}^{3+}=0.0 ;(\mathrm{H}+\mathrm{Al})=2.48 ; \mathrm{SB}=5.10 ; \mathrm{CEC}(\mathrm{t})=9.05$ and CEC $(\mathrm{T})=8.11 \mathrm{cmolc}$ $\mathrm{dm}^{-3} ; \mathrm{V}=73 \%$; P-rem $=29.9 \mathrm{mg} \mathrm{L}^{-1} ; \mathrm{OM}=2.7 \mathrm{dag} \mathrm{kg}^{-1} ; \mathrm{B}=0.7 ; \mathrm{Fe}=188 ; \mathrm{Mn}=104.4 ; \mathrm{Zn}=12$ and $\mathrm{Cu}=3.5 \mathrm{mg} \mathrm{dm}^{-3}$.

The experiment was conducted under a randomized block design with four replications. It consisted of four treatments, corresponding to a single cultivation of arrowroot (Maranta arundinacea L.) and arrowroot intercropped with crotolaria (Crotolaria juncea), having three harvest times of crotalaria plants, performed at 90, 120 and 150 days after sowing (DAS). Arrowroot 'Seta" was used as a propagation material. The experimental plot consisted of four rows spaced at $0.80 \mathrm{~m}$, with $4.0 \mathrm{~m}$ in length containing, in each row, 10 arrowroot plants spaced at $0.40 \mathrm{~m}$. In the intercropping, 50 seeds of crotalaria were sown per linear meter.

The planting of arrowroot was held in October 2012 in holes opened at a depth of $0.12 \mathrm{~m}$, where the seedlings (rhizomes) were placed with approximately $12 \mathrm{~g}$ of fresh matter and covered with soil. Crotalaria plants were sown 30 days after planting the arrowroot in furrows of $2.0 \mathrm{~cm}$ in depth, laterally to arrowroot plants, and covered by a thin layer of soil.

Neither fertilization nor liming was carried out. The control of invasive plants was carried out at 30 and 60 days after planting (DAP) the arrowroot with the help of a hoe and, at 90 DAP, ridging was performed. In the absence of rain, the crops were irrigated by sprinkling.

At 90,120 and 150 days after sowing (DAS) crotalaria (120, 150 and 180 DAP arrowroot), all crotalaria plants of the experimental plot were harvested close to the soil. In each cutting time in the three central meters of each of the two central rows $\left(4.8 \mathrm{~m}^{2}\right)$, the following were evaluated: fresh and dry matter mass and mineral composition of cut crotalaria biomass; length of arrowroot plants and incidence of invasive plants. After harvest and removal of samples for analysis, crotalaria plants were weighed and laid between the rows of arrowroot as mulch.

A sample of about $500 \mathrm{~g}$ of fresh matter, after weighing, was crushed, placed to dry in a continuous air circulation oven at $70{ }^{\circ} \mathrm{C}$ for 72 hours, weighed, ground in Willey-type mill and sent to the laboratory for chemical analysis. The length of arrowroot plants was obtained by measurements taken from ground level to the last leaf sheath insertion. The incidence of invasive plants was evaluated for each experimental unit by throwing a $0.25 \mathrm{~m}^{2}$ square into the area three times. All invasive plants present in the area occupied by the square were collected, washed, weighed and placed to dry in a continuous air circulation oven $70{ }^{\circ} \mathrm{C}$ until constant weight, ultimately resulting in the dry matter. Thirty days after the last harvest, length assessment of arrowroot plants and incidence of invasive plants using the same methodology of the harvests were carried out.

At 319 DAP arrowroot, when $50 \%$ of plants were in the aerial part senescence state, arrowroot was harvested. Eight plants were harvested in the central parts of the two useful rows. The rhizomes were classified according to HEREDIA ZÁRATE \& VIEIRA (2005) into three classes: Large $(>20 \mathrm{~cm})$, medium (12 to $20 \mathrm{~cm}$ ) and small $(<12 \mathrm{~cm})$. The rhizome of each class was numbered, weighed, and measured according to its length and diameter.

A sample of $500 \mathrm{~g}$ composed of the three rhizome classes was collected; the rhizomes were washed, chopped, and dried in a continuous air circulation oven at $70{ }^{\circ} \mathrm{C}$ for 72 hours. After drying, the material was ground in a Wiley-type mill and sent to the laboratory for analysis of macro and micronutrients. Another sample of about $500 \mathrm{~g}$ of rhizomes obtained in the same manner as the previous one was used for the process of obtaining starch. The rhizomes were washed, peeled, cut into slices and disintegrated with the aid of an industrial blender $(0.5 \mathrm{~kg}$ rhizomes $/ 0.5 \mathrm{~L}$ water) for 5 minutes. The material was sieved through 60 and 200 Tyler sieves for separation and purification of milk from the starch, respectively. Then the material was left to decant for five days where it was repeatedly washed daily. After that, the material was dried in a continuous air circulation oven at $70{ }^{\circ} \mathrm{C}$ for 72 hours, followed by weighing of starch (LEONEL \& CEREDA 2002).

The evaluated variables were submitted to normality tests (Lilliefors), additivity (Tukey method), and homoscedasticity (Barttlet), assumptions for the validation of the analysis of variance. As all variables obeyed the assumptions, without data transformation, they were submitted to analysis of variance and compared by the test of Tukey at $5 \%$ of probability. The behavior of weed incidence over time was represented by a graph. 


\section{RESULTS AND DISCUSSION}

Except for number, length, diameter and productivity of small-class rhizomes, length and diameter of medium rhizome class, and diameter of the large class, all other features of arrowroot rhizomes differ among treatments (Table 1). Cuts of crotalaria made at 120 and 150 DAS were the ones that provided lower values for number and productivity of large class rhizomes. The harvest conducted at 150 DAS provided an even smaller number of medium rhizome class and total per plant, shorter length of large class rhizomes and yield of intermediate class and total rhizome and starch productivity (Table 1).

Table 1. Number, length, diameter and yield of rhizomes of large (LR), medium (MR) and small (SR) class and total per plant (TR) and starch in "Seta" arrowroot rhizomes according to the crotalaria harvesting season in days after sowing (DAS).

\begin{tabular}{|c|c|c|c|c|c|}
\hline \multirow{2}{*}{$\begin{array}{l}\text { Rhizome } \\
\text { class }\end{array}$} & \multicolumn{4}{|c|}{ Cutting treatment } & \multirow[b]{2}{*}{$P$ value } \\
\hline & Control & 90 & 120 & 150 & \\
\hline & \multicolumn{5}{|c|}{ 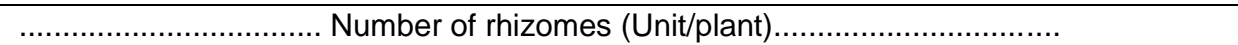 } \\
\hline$\overline{\mathrm{LR}}$ & $3.81 \mathrm{a}$ & $4.29 \mathrm{a}$ & $2.35 \mathrm{~b}$ & $1.44 \mathrm{~b}$ & 0.0003 \\
\hline MR & $5.88 \mathrm{ab}$ & $6.19 \mathrm{a}$ & $5.50 \mathrm{ab}$ & $3.32 \mathrm{~b}$ & 0.0361 \\
\hline SR & $10.63 \mathrm{a}$ & $12.38 \mathrm{a}$ & $11.85 \mathrm{a}$ & $7.54 \mathrm{a}$ & 0.0499 \\
\hline \multirow[t]{2}{*}{ TR } & $20.31 \mathrm{a}$ & $22.85 \mathrm{a}$ & $19.69 \mathrm{a}$ & $12.28 \mathrm{~b}$ & 0.0042 \\
\hline & \multicolumn{5}{|c|}{ 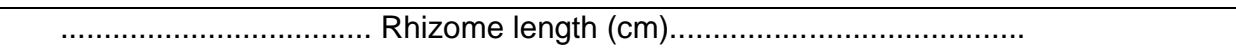 } \\
\hline$\overline{\mathrm{LR}}$ & $25.68 \mathrm{a}$ & $27.46 \mathrm{a}$ & $24.79 a b$ & $22.44 \mathrm{~b}$ & 0.0038 \\
\hline MR & $16.40 \mathrm{a}$ & $15.69 \mathrm{a}$ & $16.63 \mathrm{a}$ & $15.51 \mathrm{a}$ & 0.6871 \\
\hline \multirow[t]{2}{*}{ SR } & $10.41 \mathrm{a}$ & $9.56 \mathrm{a}$ & $9.53 \mathrm{a}$ & $9.91 \mathrm{a}$ & 0.3026 \\
\hline & \multicolumn{5}{|c|}{ 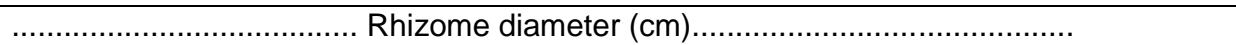 } \\
\hline$\overline{\mathrm{LR}}$ & $2.38 \mathrm{a}$ & $2.64 \mathrm{a}$ & $2.08 \mathrm{a}$ & $2.16 \mathrm{a}$ & 0.1742 \\
\hline MR & $1.74 \mathrm{a}$ & $1.53 \mathrm{a}$ & $1.62 \mathrm{a}$ & $1.75 \mathrm{a}$ & 0.4730 \\
\hline \multirow[t]{2}{*}{ SR } & $1.34 \mathrm{a}$ & $1.05 \mathrm{a}$ & $1.07 \mathrm{a}$ & $1.18 \mathrm{a}$ & 0.0568 \\
\hline & \multicolumn{5}{|c|}{ Rhizome yield (t ha $\left.{ }^{1}\right)$. } \\
\hline$\overline{\mathrm{LR}}$ & $12.19 \mathrm{a}$ & $12.66 \mathrm{a}$ & $6.66 \mathrm{~b}$ & $3.83 \mathrm{~b}$ & 0.0005 \\
\hline MR & $7.39 \mathrm{a}$ & $6.94 \mathrm{a}$ & $5.70 a b$ & $3.72 b$ & 0.0203 \\
\hline SR & $5.48 \mathrm{a}$ & $4.47 \mathrm{a}$ & $4.00 \mathrm{a}$ & $2.62 \mathrm{a}$ & 0.1340 \\
\hline \multirow[t]{2}{*}{ TR } & $25.05 \mathrm{a}$ & $24.07 \mathrm{ab}$ & $16.37 \mathrm{bc}$ & $10.16 \mathrm{c}$ & 0.0011 \\
\hline & \multicolumn{5}{|c|}{...........Starch yield $\left(\mathrm{t} \mathrm{ha}^{-1}\right) \ldots \ldots$} \\
\hline$\overline{\mathrm{TR}}$ & $1.55 \mathrm{a}$ & $1.41 \mathrm{a}$ & $1.08 \mathrm{ab}$ & $0.77 \mathrm{~b}$ & 0.0046 \\
\hline
\end{tabular}

Means, in the rows, followed by at least the same letter are not different by the test of Tukey at $5 \%$ of probability.

The crotalaria hasvested at 90 DAS provided higher results than harvesting in treatments at 120 and 150 DAS for some characteristics evaluated, however, it did not differ from control in all characteristics, including starch yield (Table 1). Thus, the hasvested at 90 DAS was not harmful to the production of arrowroot. In turn, the harvest conducted at 120 and 150 DAS, the latter in particular, were detrimental, affecting the number of rhizomes per plant and therefore the productivity of rhizomes and starch. These results corroborate with those found by VIEIRA et al. (2015), who studied the performance of arrowroot "Viçosa" intercropped with crotalaria and found that cutting the crotalaria at 150 DAS had a negative effect on arrowroot.

One explanation for the worst results found in harvests made at 120 and 150 DAS may be due to the sharp growth of crotalaria plants, which resulted in light restriction on arrowroot plants. According to GLIESSMAN (2005), when a plant is under another, the amount of light reaching its leaves may become limiting, which severely compromises growth and development. Another factor was the stress that arrowroot plants suffered due to sudden exposure to this direct radiation after the harvest of crotalaria plants. It was possible to observe that, in these treatments, symptoms of leaf scald in arrowroot on the days following the harvests promoted large reduction in photosynthetic area. Leaf scald occurs when the plant absorbs high intensity energy of sun and cannot dissipate it, resulting in oxidative damage.

Thus, the lowest yields of rhizomes and starch in treatments where arrowroot plants remained shaded for a longer period (120 and 150 DAS) may have been due to shading before harvest and photo-oxidative damage after harvesting of crotalaria. The shading prior to harvest affected the development of the plants where the plants have invested more in the expansion of leaf area in detriment to production rhizomes (GODIM et al. 2007, OLIVEIRA et al. 2011); photo-oxidative damage after harvesting crotalaria promoted reduction in the photosynthetic area.

Therefore, synchronization between the cycles of green manure and vegetables is important, as this 
will determine the best harvest time for promoting the target crop. When intercropped with okra, crotalaria harvesting at 50 DAS promoted an increase in fruit production (RIBAS et al. 2003). However, in Magali $R$ and Magda Super pepper, positive results were found when crotalaria was cut at 27 and 45 days after pepper transplantation (CESAR et al. 2007).

In this study, crotalaria harvested at 90 DAS did not affect the growth and production of arrowroot. It is possible that, in addition to the shortest light restriction period, crotalaria that was harvested and laid on the ground provided nutrients for arrowroot by mineralization process, due to the long crop cycle of arrowroot (11 months). Nevertheless, in cuts made at 120 and 150 DAS, this did not occur due to the very constitution of crotalaria, which was more lignified, presenting more dry matter mass, especially at 150 DAS (Table 2). According to ESPÍNDOLA et al. (1997), after cutting of legumes used for ground cover and green manure, temporary immobilization of nutrients occurs in biomass, with progressive release during its decomposition.

Table 2. Fresh matter (FM) and dry matter (DM) mass and macronutrient mass supplied by the aerial part of crotalaria plants and arrowroot rhizomes at harvest according to the crotalaria harvest times in days after sowing (DAS).

\begin{tabular}{|c|c|c|c|c|c|c|}
\hline \multirow{2}{*}{$\begin{array}{c}\mathrm{FM} / \mathrm{DM} / \\
\text { Macronutrients }\end{array}$} & \multicolumn{4}{|c|}{ Cutting treatment (DAS) } & \multirow{2}{*}{$P$ value } & \multirow{2}{*}{ CV $(\%)$} \\
\hline & Control. & 90 & 120 & 150 & & \\
\hline \multicolumn{7}{|c|}{ 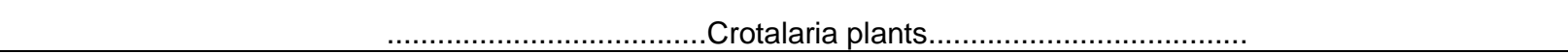 } \\
\hline $\mathrm{FM}\left(\mathrm{t} \mathrm{ha}{ }^{-1}\right)$ & - & $27.10 \mathrm{a}$ & $24.17 \mathrm{a}$ & $21.71 \mathrm{a}$ & 0.0071 & 9.98 \\
\hline $\mathrm{DM}\left(\mathrm{t} \mathrm{ha}^{-1}\right)$ & - & $5.69 \mathrm{~b}$ & $6.50 \mathrm{~b}$ & $8.78 \mathrm{a}$ & 0.5920 & 10.97 \\
\hline Nitrogen (kg ha-1) & - & $38.50 \mathrm{~b}$ & $52.25 \mathrm{a}$ & $37.75 b$ & 0.0033 & 10.99 \\
\hline Phosphorus (kg ha-1) & - & $4.40 \mathrm{c}$ & $7.80 \mathrm{~b}$ & $10.40 \mathrm{a}$ & 0.0010 & 11.47 \\
\hline Potassium $\left(\mathrm{kg} \mathrm{ha}^{-1}\right)$ & - & $84.21 \mathrm{~b}$ & $109.12 \mathrm{a}$ & $115.93 \mathrm{a}$ & 0.0147 & 10.65 \\
\hline Calcium $\left(\mathrm{kg} \mathrm{ha}^{-1}\right)$ & - & $66.00 \mathrm{ab}$ & $77.94 \mathrm{a}$ & $56.21 \mathrm{~b}$ & 0.0120 & 10.26 \\
\hline Magnesium (kg ha-1) & - & $17.64 \mathrm{~b}$ & $16.89 b$ & $158.09 \mathrm{a}$ & 0.0000 & 21.87 \\
\hline Sulfur $\left(\mathrm{kg} \mathrm{h}^{-1}\right)$ & & $5.12 b$ & $3.25 \mathrm{c}$ & $8.78 \mathrm{a}$ & 0.0006 & 12.50 \\
\hline \multicolumn{7}{|c|}{ 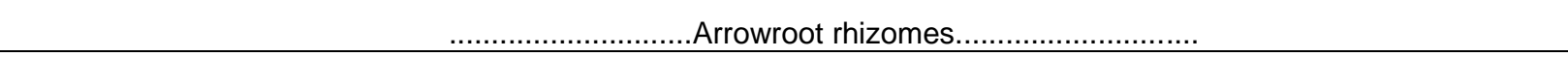 } \\
\hline $\mathrm{FM}\left(\mathrm{t} \mathrm{ha}{ }^{-1}\right)$ & $25.05 \mathrm{a}$ & $24.07 \mathrm{ab}$ & $16.37 \mathrm{bc}$ & $10.16 \mathrm{c}$ & 0.0011 & 20,10 \\
\hline $\mathrm{DM}\left(\mathrm{t} \mathrm{ha} \mathrm{C}^{-1}\right)$ & $7.33 \mathrm{ab}$ & $7.90 \mathrm{a}$ & $5.21 \mathrm{bc}$ & $3.36 \mathrm{c}$ & 0.0016 & 20.01 \\
\hline Nitrogen $\left(\mathrm{kg} \mathrm{ha}^{-1}\right)$ & $74.72 \mathrm{a}$ & $80.58 \mathrm{a}$ & $56.21 \mathrm{ab}$ & $30.98 \mathrm{~b}$ & 0.0011 & 19.96 \\
\hline Phosphorus (kg ha-1) & $2.90 \mathrm{c}$ & $3.80 \mathrm{bc}$ & $6.30 \mathrm{ab}$ & $10.40 \mathrm{a}$ & 0.0007 & 20.24 \\
\hline Potassium (kg ha-1) & $128.92 \mathrm{a}$ & $107.44 \mathrm{a}$ & $89.53 \mathrm{a}$ & $44.32 b$ & 0.0007 & 19.79 \\
\hline Calcium (kg ha-1) & $7.33 \mathrm{a}$ & $7.90 \mathrm{a}$ & $4.16 \mathrm{~b}$ & $2.35 b$ & 0.0002 & 21.28 \\
\hline Magnesium (kg ha-1) & $8.06 \mathrm{a}$ & $7.11 \mathrm{a}$ & $6.25 \mathrm{ab}$ & $4.03 \mathrm{~b}$ & 0.0067 & 19.20 \\
\hline Sulfur (kg ha-1) & $9.52 \mathrm{a}$ & $4.74 \mathrm{a}$ & $4.68 \mathrm{a}$ & $2.35 \mathrm{~b}$ & 0.0001 & 20.56 \\
\hline
\end{tabular}

Means, in the rows, followed by at least the same letter are not different by the test of Tukey at $5 \%$ of probability.

Among the analyzed characteristics, length of large class rhizomes and, above all, the number of rhizomes per plant were the ones which most contributed to the overall productivity of rhizomes; the diameter of the rhizomes had little relevance (Table 1), however. The average length of large rhizomes observed in the control and in the harvest made at 90 days was $26.6 \mathrm{~cm}$, thus higher than the average of $20.6 \mathrm{~cm}$ of length observed by HEREDIA ZARATE \& VIEIRA (2005), when evaluating the production of arrowroot from three types of propagules.

As a consequence of this, the later harvests provided lower yield values for rhizomes and starch. The harvest made at 150 DAS provided only 49.68 and $54.60 \%$ of those observed in the control and the harvest made at 90 DAS, respectively.

Besides yield of rhizomes, the starch content may vary with the crop cycle from 18.8 to $23.8 \%$ by rhizomes harvested from plants from 12 to 14-months of cycle, respectively (FERRARI et al. 2005). In this experiment, the starch content ranged from 5.85 to $7.57 \%$, and the amount of starch produced ranged from 0.77 to $1.55 \mathrm{t} \mathrm{ha}^{-1}$ (Table 1). LEONEL \& CEREDA (2002) found values higher than those of this experiment, with $24.23 \%$ starch content on a wet basis, with yields of 15 and $3.6 \mathrm{t} \mathrm{ha}^{-1}$ of rhizome and starch, respectively.

The low percentage of starch in the rhizomes in this study can be explained by the moisture content. 
FERRARI et al. (2005), when evaluating the characteristics of rhizomes and starch in different stages, found that the rhizomes collected at approximately ten months of planting showed higher moisture content $(79.7 \%)$ and lower content of other components, demonstrating that the plant would still be in the process of reserve accumulation in the rhizomes. The same authors found that only starting from the twelve months of planting that a sharp increase occurred in starch content; in this experiment, the rhizomes were harvested at approximately eleven months of planting.

Although crotalaria cutting had not provided an increase in the production of rhizomes and starch of arrowroot, the mass amount of fresh and dry matter that it provided to the soil is highlighted, since it carries significant amounts of macro and micronutrients (Tables 2 and 3). Masses of fresh and dry matter ranged from 21.17 to 27.71 and from 5.69 to $8.78 \mathrm{t} \mathrm{ha}^{-1}$, respectively (Table 2). The mass values of dry matter, particularly in the harvest conducted at 150 DAS, were similar to those obtained by PEREIRA et al. (2011), who found $8.08 \mathrm{t} \mathrm{ha}^{-1}$.

Table 3. Micronutrients supplied by the aerial part of crotalaria plants due to harvesting and by arrowroot rhizomes at harvest according to the harvest time, in days after sowing (DAS).

\begin{tabular}{|c|c|c|c|c|c|c|}
\hline \multirow{2}{*}{$\begin{array}{l}\text { Micronutrients } \\
\left(\mathrm{g} \mathrm{ha}^{-1}\right)\end{array}$} & \multicolumn{4}{|c|}{ Cutting treatment (DAS) } & \multirow{2}{*}{$P$ value } & \multirow{2}{*}{ CV $(\%$} \\
\hline & Control & 90 & 120 & 150 & & \\
\hline \multicolumn{7}{|c|}{...Crotalaria plants.. } \\
\hline Zinc & _ & $148 \mathrm{~b}$ & $182 \mathrm{~b}$ & $265 a$ & 0.001 & 11.31 \\
\hline Iron & - & $2,094 \mathrm{~b}$ & $2,280 \mathrm{~b}$ & $3,390 \mathrm{a}$ & 0.001 & 11.19 \\
\hline Manganese & - & $330 \mathrm{a}$ & $357 a$ & $334 a$ & 0.516 & 10.07 \\
\hline Copper & _ & $34 \mathrm{~b}$ & $39 a b$ & $44 \mathrm{a}$ & 0.040 & 10.45 \\
\hline Boron & & $176 \mathrm{a}$ & $220 \mathrm{a}$ & $190 \mathrm{a}$ & 0.054 & 10.32 \\
\hline \multicolumn{7}{|c|}{ Arrowroot rhizomes............................................ } \\
\hline Zinc & $95 \mathrm{a}$ & $63 \mathrm{bc}$ & $78 \mathrm{ab}$ & $37 \mathrm{c}$ & 0.001 & 19.03 \\
\hline Iron & $1,633 \mathrm{c}$ & $5,751 \mathrm{~b}$ & $15,986 \mathrm{a}$ & $1,612 \mathrm{c}$ & 0.000 & 20.64 \\
\hline Manganese & $59 \mathrm{~b}$ & 79 b & $250 \mathrm{a}$ & $47 \mathrm{~b}$ & 0.000 & 19.44 \\
\hline Copper & $29 a$ & $16 \mathrm{bc}$ & $21 \mathrm{~b}$ & $10 \mathrm{c}$ & 0.000 & 19.42 \\
\hline Boron & $46 \mathrm{a}$ & $42 \mathrm{a}$ & $48 \mathrm{a}$ & $21 \mathrm{~b}$ & 0.002 & 18.59 \\
\hline
\end{tabular}

Means, in the rows, followed by at least the same letter are not different by the test of Tukey at $5 \%$ of probability.

The lack of positive effect crotalaria on the production of arrowroot, in addition to the factors already mentioned, may be related to the lack of synchrony between the mineralization and the time of the highest nutritional requirement by the arrowroot. The release of nutrients by the legume depends on several factors that interfere with its decomposition. Temperature, aerobic conditions, moisture and soil $\mathrm{pH}$ as well as nutrient levels and the $\mathrm{C} / \mathrm{N}$ relationship of crop residues are among the main factors that determine the decomposition rate.

Over time, during the harvests conducted at 120 and 150 DAS, the amount of dry matter mass and macro and micronutrients in crotalaria mass increased; however, it seems that these were not available for the arrowroot in due time, given the fact this increase would not have been reflected in the composition of rhizomes (Tables 2 and 3). These results raise two non-exclusive hypotheses: one is that biomass of crotalaria harvested at 120 and 150 DAS did not suffer mineralization in due time for nutrients to become available for arrowroot plants; the other is that, due to the extended period of intercropping in these treatments, arrowroot was in a disadvantageous place of competition for growth factors (light, nutrients and water) with crotalaria. However, the benefits of green manure in land use over the crops must be taken into account, especially in the small family farms in order to maintain or even improve the chemical and physical characteristics of the soil with no need to spend on mineral fertilizers.

Among the advantages of using green manure intercropped with vegetables is the suppression of spontaneous vegetation. Regarding the ridging held at 90 DAP arrowroot, which corresponds to 60 DAS crotalaria, a higher growth of spontaneous vegetation was found in the single cultivation of arrowroot, especially between 90 and 120 DAS crotalaria (Figure 1). In the single cultivation, an estimated peak of $2,826.67 \mathrm{~g}$ of dry matter mass of weeds at 120 DAS crotalaria was found. From that, a reduction in weed infestation occurred due to the increase in the coverage provided by the development of arrowroots. 


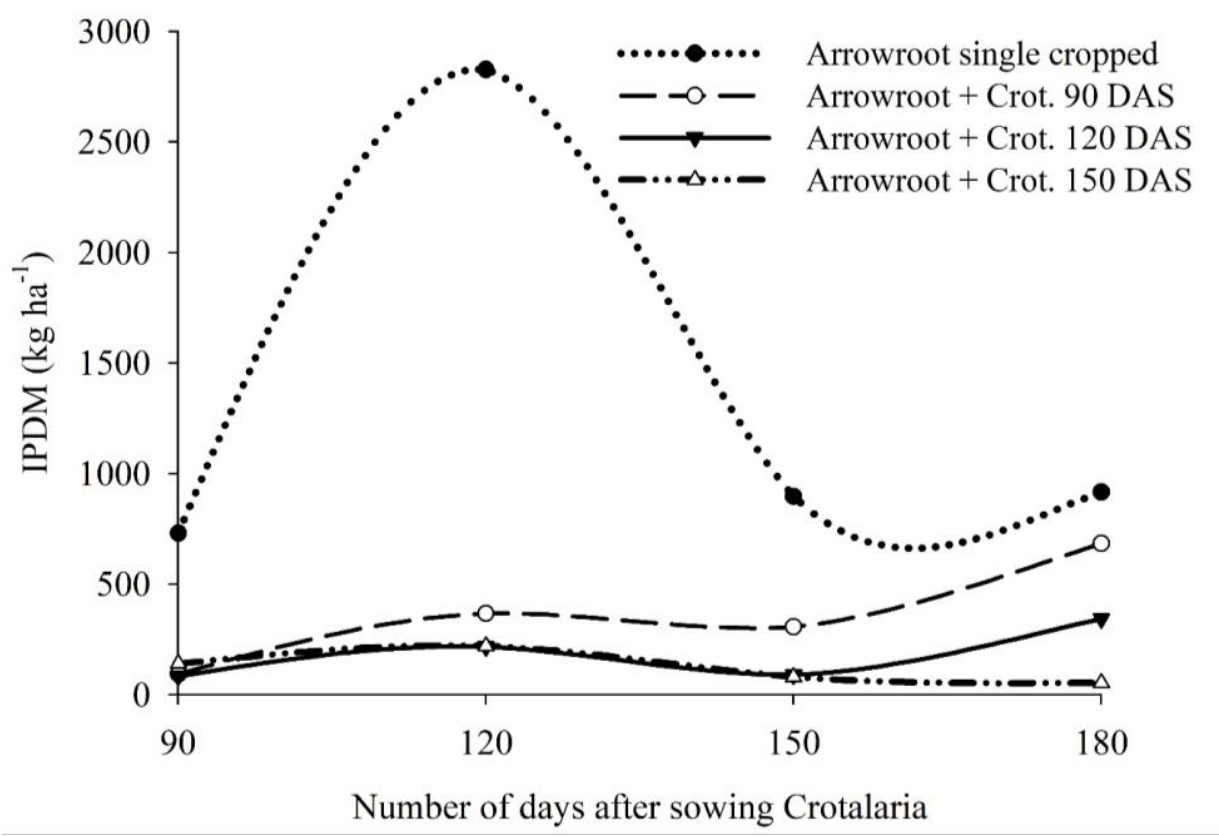

Figure 1. Values of invasive plant dry matter mass (IPDM) in $\mathrm{kg} \mathrm{ha}^{-1}$ in the evaluations carried out at 90, 120, 150 and 180 DAS crotalaria in different treatments.

When crotalaria hasvested was performed at 90 DAS, a linear increase in dry matter mass of weeds occurred. However, this increase was small, showing that the mass of crotalaria laid on the ground after harvesting provided some control over invasive plants. OLIVEIRA et al. (2004) also found that the material cut from crotalaria laid on the soil was effective in weed control, reducing the cost with labor for weeding.

When crotalaria was cut at 120 DAS, a low infestation of invasive plants throughout the crop cycle was found with estimated maximum of $366.67 \mathrm{~g}$ observed at 120 DAS crotalaria. In this case, the shading caused by crotalaria before the cut did not allow the growth of invasive plants. Similar behavior was observed in the 150 DAS cutting treatment. In both treatments, mean values of weed incidence were lower than in the other treatments.

\section{CONCLUSION}

From the results obtained in this experiment, the intercropping between Crotalaria juncea with arrowroot is agronomically viable. However, considering only the production of arrowroot rhizomes, harvesting crotalaria plants after 90 days of sowing or 120 days after arrowroot planting would not be recommended. Arrowroot and Crotalaria juncea intercropping reduces infestation of weed in the area.

\section{ACKNOWLEDGMENTS}

To CNPq and FAPEMIG for the financial support for carrying out the experiment.

\section{REFERENCES}

CEREDA MP. 2002. Agricultura: tuberosas, amiláceas Latino Americanas, série: culturas de tuberosas, amiláceas Latino Americanas II. São Paulo: Fundação Cargill. 540p.

CESAR MNZ et al. 2007. Desempenho do pimentão em cultivo orgânico, submetido ao desbaste e consórcio. Horticultura Brasileira 25: 322-326.

ESPÍNDOLA JAA et al. 1997. Adubação verde: estratégia para uma agricultura sustentável. Rio de Janeiro: Embrapa. 20p.

FERRARI TB et al. 2005. Características dos rizomas e do amido de araruta (Maranta arundinacea) em diferentes estádios de desenvolvimento da planta. Brazilian Journal of Food Technology 8: 93-98.

GLIESSMAN SR. 2005. Agroecologia: processos ecológicos em agricultura sustentável. 3.ed. Porto Alegre: UFRGS. $654 p$.

GODIM ARO et al. 2007. Crescimento, partição de fotoassimilados e produção de rizomas em taro cultivado sob sombreamento artificial. Horticultura Brasileira 25: 418-428.

HEREDIA ZÁRATE NA \& VIEIRA MC. 2005. Produção da araruta 'Comum' proveniente de três tipos de propágulos. Ciências e Agrotecnologia 29: 995-1000.

LEONEL M \& CEREDA MP. 2002. Caracterização físico-química de algumas tuberosas amiláceas. Ciência e Tecnologia de Alimentos 22: 65-69.

Rev. Ciênc. Agrovet., Lages, SC, Brasil (ISSN 2238-1171) 
MAPA. 2010. Ministério da Agricultura, Pecuária e Abastecimento. Secretaria de Desenvolvimento Agropecuário e Cooperativismo. Manual de hortaliças não convencionais. Brasília: ACS. 92p. Disponível em: http://www.abcsem.com.br/docs/manual_hortalicas_web.pdf. Acesso em: 21 set. 2017.

MOURA WM et al. 2005. Pesquisas em sistemas agroecológicos e orgânicos da cafeicultura familiar na zona da mata mineira. Belo Horizonte: EPAGRI. 46-75p. (Informe agropecuário 26).

OLIVEIRA FL et al. 2004. Desempenho do inhame (taro) em plantio direto e no consórcio com crotalária, sob manejo orgânico. Horticultura Brasileira 22: 638-641.

OLIVEIRA FL et al. 2005. Desempenho do consórcio entre repolho e rabanete com pré-cultivo de crotalária, sob manejo orgânico. Horticultura Brasileira 23: 184-188.

OLIVEIRA FL et al. 2011. Crescimento e acumulação de nutrientes em plantas de taro sob níveis de sombreamento artificial. Horticultura Brasileira 29: 291-298.

PEREIRA LC et al. 2011. Comportamento de cultivares de milho consorciados com Crotalaria juncea: estudo preliminar. Revista Brasileira de Agroecologia 6: 191-200.

PUIATTI M et al. 2015. Consorciação taro e crotalária manejada com corte rente ao solo e poda na altura do dossel. Revista Ceres 62: 275-283.

RIBAS RGT et al. 2003. Manejo da Adubação Verde com Crotalária no Consórcio com o Quiabeiro sob Manejo Orgânico. Rio de Janeiro: Embrapa. 4p. (Comunicado Técnico 59).

SOUZA JL \& GUIMARÃES GP. 2013. Rendimento de massa de adubos verdes e o impacto na fertilidade do solo em sucessão de cultivos orgânicos. Bioscience Journal 29: 1796-1805.

SOUZA JL et al. 2015. Desenvolvimento de hortaliças e atributos do solo com adubação verde e compostos orgânicos sob níveis de N. Horticultura Brasileira 33: 19-26.

VARGAS TO et al. 2011. Influência da biomassa de leguminosas sobre a produção de repolho em dois cultivos consecutivos. Horticultura Brasileira 29: 562-568.

VIEIRA JCB et al. 2015. Desempenho da araruta 'Viçosa' consorciada com crotalária. Revista Brasileira de Ciências Agrárias 10: 518-524. 